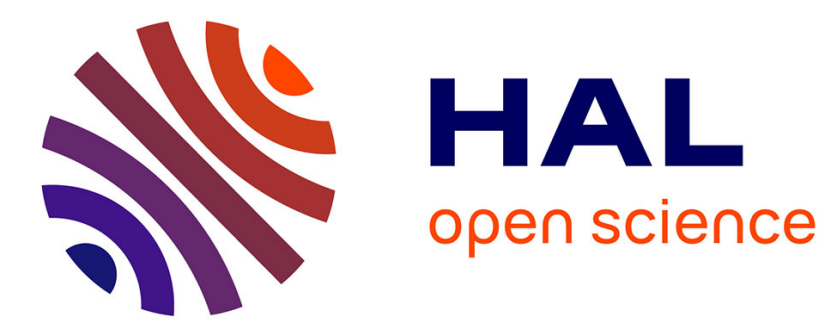

\title{
"Contagion": The determinants of governments' public health responses to COVID-19 all around the world
}

Simon Porcher

\section{To cite this version:}

Simon Porcher. "Contagion": The determinants of governments' public health responses to COVID-19 all around the world. 2020. halshs-02567286

\section{HAL Id: halshs-02567286 \\ https://shs.hal.science/halshs-02567286}

Preprint submitted on 7 May 2020

HAL is a multi-disciplinary open access archive for the deposit and dissemination of scientific research documents, whether they are published or not. The documents may come from teaching and research institutions in France or abroad, or from public or private research centers.
L'archive ouverte pluridisciplinaire HAL, est destinée au dépôt et à la diffusion de documents scientifiques de niveau recherche, publiés ou non, émanant des établissements d'enseignement et de recherche français ou étrangers, des laboratoires publics ou privés. 


\title{
"Contagion": The determinants of governments' public health responses to COVID-19 all around the world
}

\author{
Simon Porcher ${ }^{1}$ \\ IAE Paris - Université Paris I Panthéon-Sorbonne
}

\begin{abstract}
To respond to the COVID-19 outbreak, governments all around the world have implemented public health measures that have resulted in different policies to contain the spread of the virus and to support the economy. These measures include travel restrictions, bans on mass gatherings, school closures and domestic lockdowns, among others. This paper presents a unique dataset of governments' responses to COVID-19. The dataset codes the policy interventions with their dates at the country level for more than 180 countries. To facilitate cross-country and crosstime comparisons, the paper builds on different measures to create an index of the rigidity of governments' responses to COVID-19. The index shows that responses to the pandemic vary across countries and across time. The paper also investigates the determinants of governments' public health responses by focusing on the timing of contamination, the health risk of the population and health quality.
\end{abstract}

Keywords: COVID-19, public health, comparative public administration, quality of government.

\section{EVIDENCE FOR PRACTICE}

- The paper introduces an index of rigidity of governments' responses to COVID-19.

- The index shows that governments' responses differ across the world and provides insightful information for academics and governments.

- The determinants of the differences in governments' responses are the timing and the intensity of contamination, health quality and demographic characteristics of the population.

\footnotetext{
${ }^{1}$ IAE Paris - Université Paris I Panthéon-Sorbonne. Contact : porcher.iae@univ-paris1.fr. I am thankful to Lorena Demichelis who provided excellent research assistance.
} 


\section{INTRODUCTION}

In December 2019, Chinese health authorities started monitoring a new virus, COVID-19, which rapidly spread all around the world, posing a major challenge to governments globally. In the beginning of April 2020, all countries were affected by the virus, and there were more than 1.5 million cases and more than 95,000 deaths linked to the virus. Governments have implemented a wide range of responses to the spread of the virus in their population. Common measures include schools closures, travel restrictions, restaurants closures, bans on mass gatherings and sporting events, and domestic lockdowns. While the global response to the virus is unique in the context of human history, little is known thus far of the determinants of measures adopted by governments.

This paper introduces a novel index, tracking 10 national public health policies implemented to counter the spread of COVID-19 in more than 180 countries. The index captures by country and on a daily basis the rigidity of governments' public health responses to the pandemic between January 1, 2020, and April 14, 2020. The index allows us to map the geographic diversity and changes over the first quarter of 2020 in governments' responses to COVID-19 and to understand the determinants of governments' actions.

At the date this writing, most governments around the world are facing an increasing number of cases, and it is too early to study the relationship between governments' public health measures and the spread of contamination in a cross-country setting (epidemiological studies are only focused on China, where the curve of contamination has been flattened; see, for example, Tian et al. 2020; Kraemer et al. 2020).

However, governments have implemented measures to contain the pandemic which differ in their stringency. In the descriptive statistics, the index shows that on April 14, Western European countries implemented the harshest policies in terms of public health. The index also shows that some countries were particularly active in preventing the spread of the disease in their territory by applying strict measures of containment before the first death. The focus of the paper is then to understand the determinants of stringent national policies. To do so, we model the rigidity of governments' responses as the results of the number of cases, the timeline and geography of the contamination and the quality of national health systems and public services. The results show 
that all the variables have a significant effect on the rigidity of governments' responses and that the timeline and the number of cases are important drivers of the rigidity of the measures. The results also suggest that governments might react too late to properly contain the pandemic.

The paper provides some comparative analyses of governments' responses to the pandemic and is of interest for both practitioners and academics. The paper participates in the effort of building an index (Elgin et al. 2020; Hale et al. 2020; Noy et al. 2020) that might be used by other researchers and practitioners to study and clarify the differences in the nature of governments' responses to COVID-19. The paper is also of interest for researchers in comparative public administration, as it creates a unique dataset ${ }^{2}$ mapping the different public health policies implemented by governments all around the world - including those of developing countries - to address this new disease.

The remainder of the paper is organized as follows. The next section introduces the methodology to build the index and the empirical model used to estimate the determinants of governments' rigidity. We then discuss the key differences between countries and estimate the determinants of governments' rigidity. A conclusion follows.

\section{METHODOLOGY AND VARIABLES}

\section{GOVERNMENTS' RESPONSES TO COVID-19}

To measure the rigidity of governments' responses to COVID-19, we created an index based on the number of measures taken by governments. The index is based on cross-country information reported by the Assessment Capacities Project (ACAPS), the International Monetary Fund (IMF), the International Institute for Democracy and Electoral Assistance (IDEA) and the United Nations Educational Scientific and Cultural Organization (UNESCO). The index is built using information on a set of 10 policies: bans on mass gatherings, bans on sporting and recreational events, restaurant and bar closures, domestic lockdowns, school closures, travel restrictions, declarations of states of emergency, public testing, enhanced surveillance and the postponement of elections. Each policy is coded 0, 0.5 or 1, depending on whether it was not implemented, partially implemented or strictly implemented. For example, school closure is coded 0 if no

\footnotetext{
${ }^{2}$ The dataset is available on the following repository: https://github.com/simonporcher/COVID-19-GovernmentsResponses.
} 
measure is taken, 0.5 if schools are partially closed at the national level, e.g., only in a given region, and 1 if all schools are nationally closed. If restaurants are opened but limited in terms of the individuals they can welcome, the variable is coded 0.5. Enhanced surveillance is coded 1 if mobile phone apps for tracing contaminated people are implemented and 0 if not. Postponing elections is coded only if elections were postponed and as a missing variable if no elections were programmed. Countries such as France or the United States, which postponed only a part of their elections, are coded as 0.5 . Policies are coded on a daily basis: if a policy becomes more or less rigid, then its coding changes on the day of the implementation. Further details on the coding are provided in Appendix A1. The final dataset is made of 10,365 country-day observations. A total of 189 countries are covered. The main economies cover the whole period, from January 1 to April 14, 2020.

The various measures constitute a homogeneous set of variables. The first component of the principal component analysis of the variables shows that they explain more than $70 \%$ of the variance, and the weights of each variable are between 0.295 and 0.363 (see appendix A2). As the principal component analysis shows that the different variables seem to have relatively equal weight, we create a simple index that is the average of the different coded measures and ranges between 0 and 1 .

The index built in the paper can be related to the effort of other academics to map governments' responses to the pandemic. Hale et al. (2020) provide a dataset of governments' responses that includes different variables related to public health, economic interventions, public campaigns and research incentives for a vaccine. Their great — and concomitant—work leads to the creation of a stringency index from 0 to 100. Our index differs in several manners from that of Hale et al. (2020). First, the focus of the dataset is exclusively on governments' public health responses, rather than including economic responses that often depend on independent institutions, e.g., central banks or regional institutions such as the European Union. Second, our dataset considers elections to be key variable. Elections are an important moment in democracies, and postponing elections might be interpreted as the will of the governing power to influence the results of elections. Finally, it covers in a detailed manner the responses to COVID-19 in developing countries, particularly African countries, thanks to the information provided by our sources. 
Other datasets mapping government interventions are found in economics. Elgin et al. (2020) created an index of economic policies to respond to COVID-19 by collecting information on the nature and the range of governments' economic interventions. Noy et al. (2020) provided an index of economic risk by world regions, depending on various indicators of economics, health and the spread of the pandemic. The latter provides insightful information on global risk but does not consider "outputs" such as government measures.

\section{MODEL TO ESTIMATE THE DETERMINANTS OF GOVERNMENTS' RIGIDITY}

To understand the rigidity of the public health response across countries, we use a simple ordinary least squares (OLS) model regressing the index with some other variables that might capture the country-level risk of COVID-19. Different variables are identified as determinants of the rigidity of governments' response to COVID-19. An important measure is the number of cases relative to the population. The number of cases is collected by the European Centre for Disease Prevention and Control on a daily basis. ${ }^{3}$ We might indeed expect a strong relationship between the number of cases and the rigidity of the response. To control for the differences in demography, we consider the ratio of accumulated cases to the total population of the country. We also added several variables collected by the World Bank for 2018. The first is government effectiveness, which measures the quality of the provision of public services, the quality of bureaucracy and the credibility of the government's commitment to such policies. We expect more effective governments to give more rigid responses to the pandemic. The other measures of the World Bank are health spending as a percentage of GDP, the ratio of the population older than 65 years old and the density of the population per square kilometer. These measures might impact the rigidity of governments' responses. Indeed, governments with a higher ratio of the population aged older than 65 years or greater population density have a higher risk of death due to COVID-19. We also add the Healthcare Access and Quality Index for 2015 (GBD 2015 Healthcare Access and Quality Collaborators, 2017), which quantifies personal healthcare access and quality for 195 countries based on reported causes of death and risk factors. Countries with greater access to healthcare might be less restrictive of liberties, as their health system might be more capable of addressing the challenges of COVID-19. Finally, two important variables might

\footnotetext{
${ }^{3}$ https://www.ecdc.europa.eu/en/publications-data/download-todays-data-geographic-distribution-covid-19cases-worldwide
} 
have an impact on the rigidity of governments' responses to COVID-19: distance to China in kilometers could explain the timing of the response to the health crisis, and the number of days since the first death in each country is an important determinant of governments' responses. We also added continent dummies as controls. Descriptive statistics are provided in Appendix A3.

We use the following OLS model to test the relationship between rigidity and various measures of risk:

$$
\text { Rigidity }_{i t}=\beta_{i j t} \times \text { Risks }_{i j t}+b+\varepsilon_{i}
$$

Rigidity $_{i t}$ is the value of the index of rigidity for country $i$ at time $t$. Risks are measured via different variables $j$ for each country $i$ at time $t$.

\section{RESULTS}

\section{RIGIDITY OF RESPONSES ALL AROUND THE WORLD}

Figure 1 maps the rigidity of governments' responses all around the world. The map shows that the most rigid policies are found in Western Europe, where quarantine policies were implemented at the national level following a strong increase in the number of cases. The group with an index between 0.65 and 0.75 includes countries such as Germany, South Korea and Switzerland, which have less rigid policies but still sharp control of the pandemic. Most countries in Asia are in the group of countries that score between 0.5 and 0.65 . While being close to China, these countries usually took early measures to avoid the spread of the virus and did not have to quickly apply rigid public health policies, unlike Western European countries. The less rigid countries are countries with fewer cases or localized, rather than nationalized, policies to the COVID-19.

The timing of the response varies from one country to another. Countries that quickly responded with rigid measures to the pandemic might have better control of the number of cases. Figure 3 maps the recorded rigidity of governments' responses on the day of the first death in their territory. "Harsh" countries, with an index greater than 0.5 on the day of the first death, have taken the potential spread of the pandemic seriously and have implemented immediate and rigid measures to contain it. The timeline of the spread of the pandemic in each country is important in clarifying the map presented in Figure 2. "Harsh" countries-especially those located in Africa or Latin America-are often countries that implemented similar measures to those observed in 
Europe and the United States before having any deaths in their territory. Some of these countries did not expect the pandemic but rather followed the general movement of public health responses.

Figure 3 shows the timing of the response and the number of daily cases for a selection of countries (Israel, Singapore, France and the United States) depending on the number of days after the first death in the territory. The timing of the response (blue line) follows the apparitions of cases (red line) on the territory. The steep blue lines of France and the United States several days after the first death show that these countries quickly increased the rigidity of their response to the pandemic, following the sharp increase in the number of cases. Both France and the United States take stronger measures when the number of cases is increasing quickly. In contrast, in Israel and Singapore, the rigidity of the response was already at the maximum level before the first death in the territory. It shows that countries differ in the timing of the response.

The timing of the response, as much as the rigidity, seems to be important in explaining the number of cases and deaths. For example, the Pearson correlation between our index of rigidity and the cumulative number of cases $(\rho=0.138)$ or deaths $(\rho=0.156)$ is relatively low. However, the correlation between the value of the index on the day of the first death and the accumulated number of cases $(\rho=-0.308)$ and deaths $(\rho=-0.267)$ on April 14 is much higher and negative. This suggests that what matters in limiting the number of cases (and deaths) is the rigidity of the response before the first death rather than the rigidity of the response following the first death. Indeed, several studies (Baud et al. 2020; Wang et al. 2020) show that the period of incubation is between 2 and 14 days, the mortality rate is approximately 5\% and the time between the detection and death of patients is a couple of weeks. Before the implementation of any strict public health measure, one death indicates that there were 20 infected people a month ago who themselves contaminated between 2 and 3 individuals in a week (Chinazzi et al. 2020), creating a cascade of contamination that is difficult to stop after the fact.

\section{THE DETERMINANTS OF THE RIGIDITY OF GOVERNMENTS' RESPONSES}

The results of OLS regressions are reported in Table 1. Column 1 reports the results for the observed value of the index at time $t$ in country $i$. Column 2 shows the results for the value of the 
index the day of the first death in a given country $i$. In column 2 , the model considers only the days before the first death, while the full dataset is considered in column 1 .

The results in column 1 show that there are two groups of variables influencing our index of rigidity. Government effectiveness, health spending and the Health Access and Quality Index have a negative impact on the index. Countries with a good health system and effective government tend to be less rigid in terms of health policies than are countries that score high on these indices. In contrast, the percentage of cases in the population, the distance to China, and the number of days after the first death in each country are indicators that have a positive impact on our index. The number of cases and the number of days after the first death in a given country are important triggers of the rigidity of health policies implemented against the pandemic. The distance to China was expected to have a negative impact on the index; however, descriptive statistics on the index show that harsher policies are found in Western Europe or in some African or Latin American countries than in Asia. This can be because Asian countries had more stringent policies in January, when the first cases appeared in China, while other countries had to rapidly address a fast-growing number of contaminations in February-March.

In column 2, the model explains the level of rigidity on the day of the first death. As in column 1, the number of cases is an important driver. As one could expect, the health risk measures of the different countries have a significant impact on the rigidity of the index on the first death. Countries with higher spending in health relative to GDP, higher population density, a larger share of the population aged older than 65 years and a lower Health Access and Quality Index are less rigid than other countries are. The continent dummies also show that countries not located in Asia experience lower levels of rigidity before any death occurs in their territory. The results show that countries with better health systems, and lower demographic risks, tend to be less rigid in their responses to COVID-19.

\section{CONCLUSIONS AND FURTHER RESEARCH}

This paper presents a new cross-country index measuring the rigidity of governments' public health responses to COVID-19 (IGRC). Ten health policy responses were coded on a daily basis from January 1 - April 14, 2020, for more than 200 countries. The final index aggregates the different coded health policy responses. The present paper also tries to explain the differences 
between governments in their responses. The results show some significant correlations between the number of days after the first death, the accumulated cases and some measures of the quality of health public services at the country level, which might explain cross-country differences in the index. Further research conducted when the pandemic will hopefully be stabilized could relate the index with the number of cases in the different countries.

There are of course limitations to considering national-level policies implemented by governments. States in the United States have different responses depending on the spread of the virus; China imposed strict quarantine measures in some parts of the countries but not in others. The index might underestimate the rigidity of the measures taken in some countries. Moreover, the index adds the different measures taken but does not control for the correct implementation of the measures. The current work of the authors is now focused on the variety of measures observed in the different states of the United States and in the different provinces of China. 


\section{REFERENCES}

ACAPS, 2020. COVID-19 government measures dataset, https://www.acaps.org/specialreport/covid-19-government-measures-update-0

Baud, David, Qi Xiaolong, Karin Nielsen-Saines, Didier Musso, Léo Pomar and Guillaume Favre. 2020. Real estimates of mortality following COVID-19 infection. The Lancet Infectious Diseases, in press.

Chinazzi, Matteo, Jessica T. Davis, Marco Ajelli, Corrado Gioannini, Maria Litvinova, Stefano Merler, Ana Pastore y Piontti, Kunpeng Mu, Luca Rossi, Kaiyuan Sun, Cécile Viboud, Xinyue Xiong, Hongjie Yu, M. Elizabeth Halloran, Ira M. Longini Jr. and Alessandro Vespignani. 2020. The effect of travel restrictions on the spread of the 2019 novel coronavirus (COVID-19) outbreak. Science, in press.

Elgin, Ceyhun, Gokce Basbug and Abdullah Yalaman. 2020. Simulation Policy Index. COVID Economics, 3.

GBD 2015 Healthcare Access and Quality Collaborators. 2017. Healthcare Access and Quality Index based on mortality from causes amenable to personal health care in 195 countries and territories, 1990-2015: A novel analysis from the Global Burden of Disease Study 2015. The Lancet, 390(10091), pp. 231-266.

Hale, Thomas, Anne Petherick, Toby Phillips and Samuel Webster. 2020. Variations in Government responses to COVID-19. BSG-WP-2020/031.

IDEA, 2020. Global overview of COVID-19: Impact on elections, https://www.idea.int/newsmedia/multimedia-reports/global-overview-covid-19-impact-elections

IMF, 2020. Policy responses to COVID-19, https://www.imf.org/en/Topics/imf-andcovid19/Policy-Responses-to-COVID-19.

Kraemer, Moritz U.G., Chia-Hung Yang, Bernardo Gutierrez, Chieh-Hsi Wu, Brennan Klein, David M. Pigott, Open COVID-19 data working Group, Louis du Plessis, Nuno R. Faria, Ruoran Li, William P. Hanage, John S. Brownstein, Maylis Layan, Alessandro Vespignani, Huaiyu Tian, Christopher Dye, Oliver G. Pybus and Samuel V. Scarpino. 2020. The effect of human mobility and control measures on the COVID-19 epidemic in China. Science, in press.

Noy, Ilan, Nguyen Doan, Benno Ferrarini and Donghyun Park. 2020. Economic risk by country. COVID Economics, 3.

Tian, Huaiyu, Yonghong Liu, Yidan Li, Chieh-Hsi Wu, Bin Chen, Moritz U. G. Kraemer, Bingying Li, Jun Cai, Bo Xu, Qiqi Yang, Ben Wang, Peng Yang, Yujun Cui, Yimeng Song, Pai Zheng, Quanyi Wang, Ottar N. Bjornstad, Ruifu Yang, Byan T. Grenfell, Oliver G. Pybus and 
Christopher Dye. 2020. An investigation of transmission control measures during the first 50 days of the COVID-19 epidemic in China. Science, in press.

UNESCO, 2020. COVID-19 Educational disruption and response, https://en.unesco.org/covid19/educationresponse.

Wang, Dawei, Bo Hu, Chang Hu, Fangfang Zhu, Xing Liu, Jing Zhang, Binbin Wang, Hui Xiang, Zhenshun Cheng, Yong Xiong, Yan Zhao, Yirong Li, Xinghuan Wang and Zhiyong Peng. 2020. Clinical characteristics of 138 hospitalized patients with 2019 novel coronavirus-infected pneumonia in Wuhan, China. JAMA, Feb. 72020. 
Figure 1: Map of the Rigidity of Governments' Responses to COVID-19

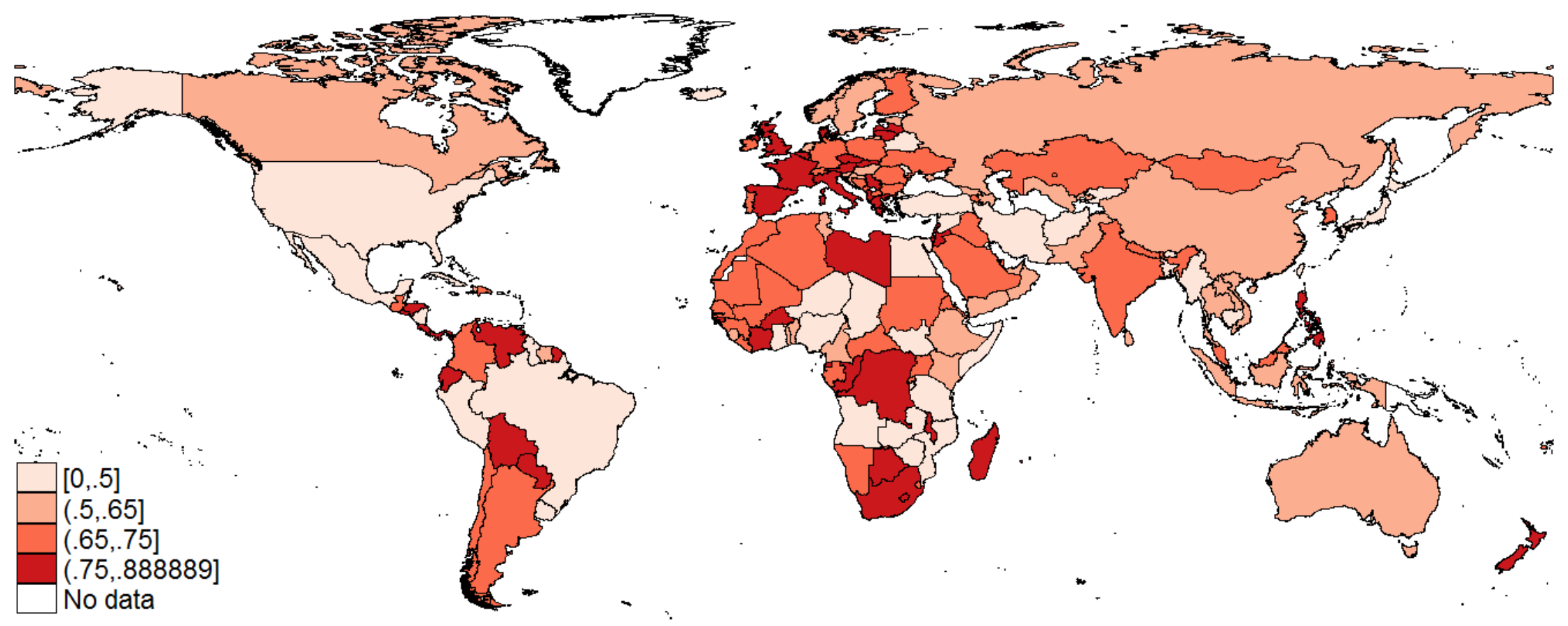

Note: The index ranges between 0 and 1, with 0 being the lowest possible value (no public health response to COVID-19) and 1 being the highest value (all potential listed policies are implemented at the national level). 
Figure 2: Map of the Rigidity of Governments' Responses to COVID-19 on the day of the first death for a given country

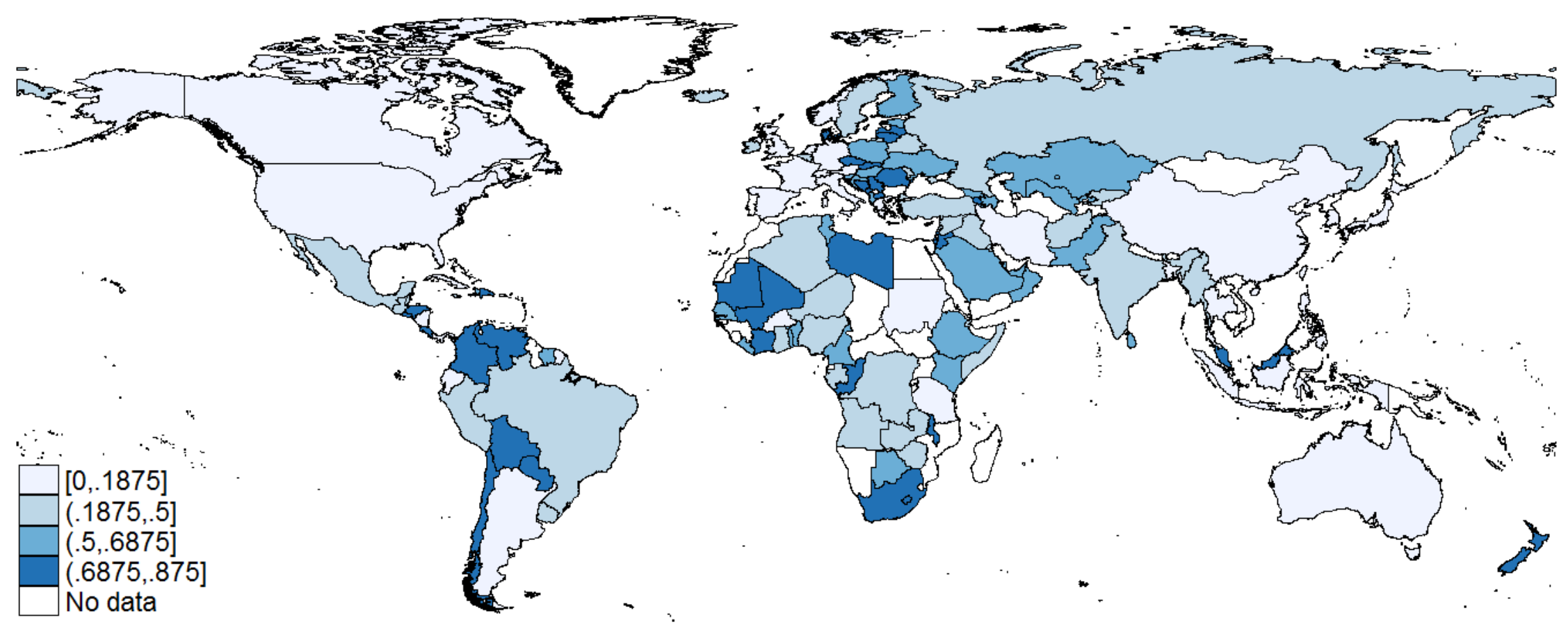

Note: The index ranges between 0 and 1, with 0 being the lowest possible value (no public health response to COVID-19) and 1 being the highest value (all potential listed policies are implemented at the national level). 
Figure 3: Rigidity of government responses (left axis) and the number of cases (right axis)
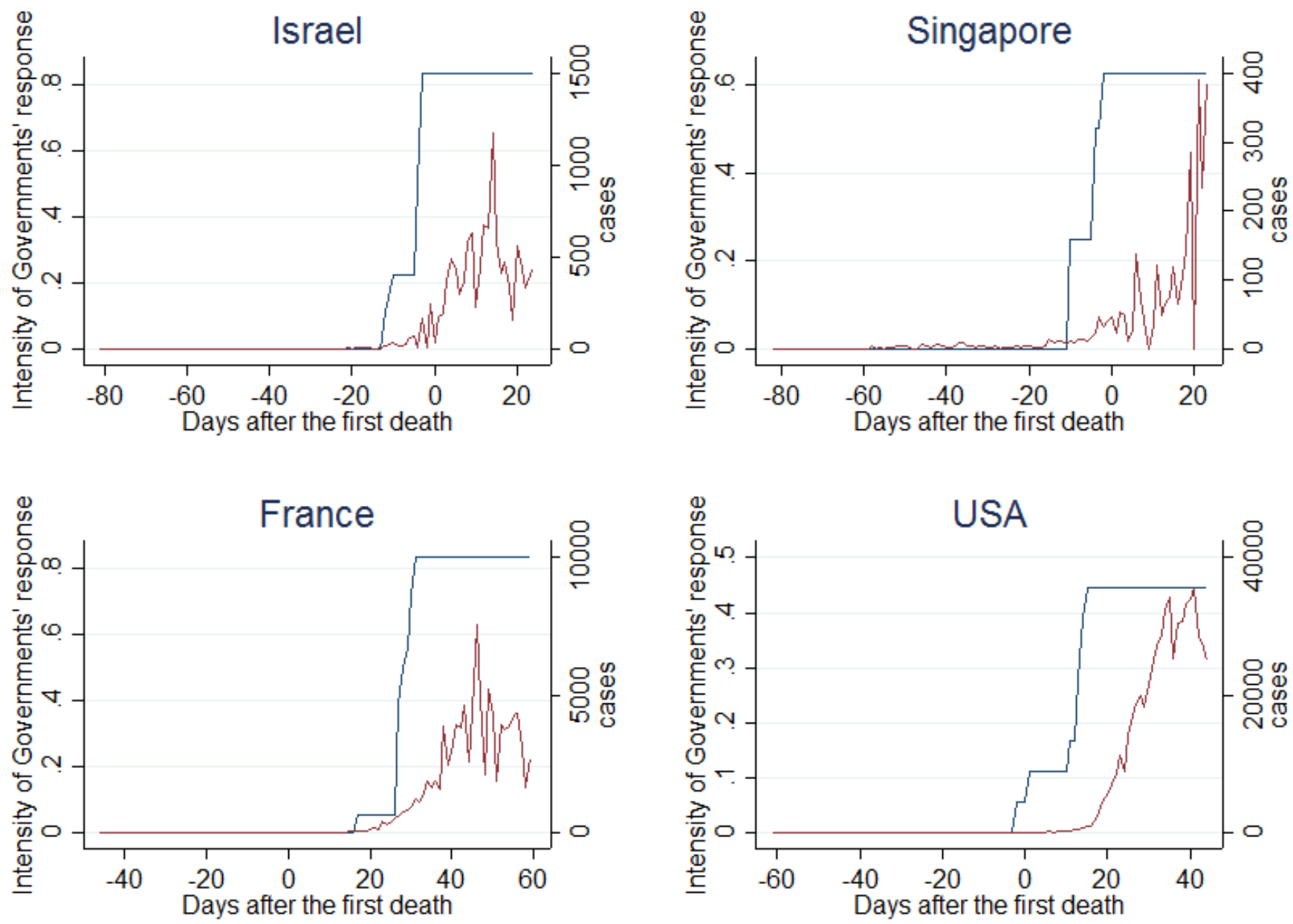
Table 1: The determinants of the rigidity of governments' responses to COVID-19

\begin{tabular}{|c|c|c|}
\hline VARIABLES & $\begin{array}{c}\text { (1) } \\
\text { Rigidity }\end{array}$ & $\begin{array}{l}\text { (2) } \\
\text { Rigidity on the day of the } \\
\text { first death }\end{array}$ \\
\hline Cases (\% population) & $\begin{array}{c}\mathbf{1 . 7 4 8} * * * * \\
(0.194)\end{array}$ & $\begin{array}{c}\mathbf{8 . 6 8 6} * * * * \\
(1.324)\end{array}$ \\
\hline Government effectiveness & $\begin{array}{c}-\mathbf{0 . 0 1 3 1} * * * * \\
(0.00481)\end{array}$ & $\begin{array}{l}-0.00467 \\
(0.00639)\end{array}$ \\
\hline Health to GDP \% & $\begin{array}{c}-\mathbf{0 . 0 4 7 6} * * * * \\
(0.00322)\end{array}$ & $\begin{array}{c}-\mathbf{0 . 0 8 4 3} * * * \\
(0.00437)\end{array}$ \\
\hline Population $>65$ & $\begin{array}{c}0.00722 \\
(0.00443)\end{array}$ & $\begin{array}{l}\mathbf{0 . 0 3 9 1} * * * * \\
(0.00585)\end{array}$ \\
\hline Health Access and Quality Index & $\begin{array}{c}-\mathbf{- 0 . 0 2 4 3 * * * *} \\
(0.00612)\end{array}$ & $\begin{array}{c}-\mathbf{- 0 . 0 4 3 0} * * * \\
(0.00786)\end{array}$ \\
\hline Population density & $\begin{array}{c}0.00232 \\
(0.00381)\end{array}$ & $\begin{array}{c}\mathbf{0 . 0 2 1 0} * * * * \\
(0.00313)\end{array}$ \\
\hline Distance to China & $\begin{array}{c}\mathbf{2 . 1 3 e - 0 5 * * * *} \\
(1.83 \mathrm{e}-06)\end{array}$ & $\begin{array}{c}\mathbf{3 . 6 7 e - 0 5}^{* * * *} \\
(2.53 \mathrm{e}-06)\end{array}$ \\
\hline Days after first death & $\begin{array}{c}\mathbf{0 . 0 0 5 9 8} * * * * \\
(8.83 \mathrm{e}-05)\end{array}$ & $\begin{array}{c}-0.000800 * * * \\
(0.000155)\end{array}$ \\
\hline Africa & $\begin{array}{l}-0.0225 \\
(0.0137)\end{array}$ & $\begin{array}{c}-0.179 * * * \\
(0.0190)\end{array}$ \\
\hline America & $\begin{array}{c}-0.0932 * * * \\
(0.0191)\end{array}$ & $\begin{array}{c}-0.315^{* * * *} \\
(0.0247)\end{array}$ \\
\hline Europe & $\begin{array}{c}0.0573 * * * \\
(0.0105)\end{array}$ & $\begin{array}{c}-0.105 * * * \\
(0.0145)\end{array}$ \\
\hline Pacific & $\begin{array}{l}-0.0192 \\
(0.0182)\end{array}$ & $\begin{array}{c}0.0320 \\
(0.0322)\end{array}$ \\
\hline Constant & $\begin{array}{l}0.215 * * * \\
(0.00959)\end{array}$ & $\begin{array}{c}0.234 * * * \\
(0.0157)\end{array}$ \\
\hline $\begin{array}{l}\text { Observations } \\
\text { R-squared }\end{array}$ & $\begin{array}{l}6,929 \\
0.504\end{array}$ & $\begin{array}{l}5,100 \\
0.153\end{array}$ \\
\hline Countries covered & 126 & 126 \\
\hline
\end{tabular}

Note: The regression is a simple ordinary least square regression. In column 1, the dependent variable is the index of rigidity. In column 2, the dependent variable is the index of rigidity on the day of the first death in a given territory. The number of days after the first death controls for time. Continent fixed-effects and distance to China control for countries fixed-effects. Robust standard errors are in parentheses, with $* \mathrm{p}<0.1,{ }^{* *} \mathrm{p}<0.05$ and ${ }^{* * *} \mathrm{p}<0.01$. 


\section{ONLINE APPENDIX}

\section{A1. CODING SCHEME}

Table A1. Variables, sources and coding schemes

\begin{tabular}{|c|c|c|c|}
\hline Variables & Primary source & Secondary source & Coding scheme \\
\hline Bans on mass gatherings & ACAPS & IMF & $\begin{array}{l}1 \text { if the ban is national, } 0.5 \text { if the ban is localized and } 0 \text { if } \\
\text { there is no ban. }\end{array}$ \\
\hline Schools closures & UNESCO & IMF & $\begin{array}{l}1 \text { if the closure is national, } 0.5 \text { if the ban is localized and } 0 \\
\text { if there is no ban. }\end{array}$ \\
\hline Travel restrictions & ACAPS & IMF & $\begin{array}{l}1 \text { if the restriction is global (border closed/commercial } \\
\text { flights cancelled), } 0.5 \text { if the restriction is targeted to some } \\
\text { countries and } 0 \text { if there are no restrictions. }\end{array}$ \\
\hline Domestic lockdowns & ACAPS & IMF & $\begin{array}{l}1 \text { if the lockdown is national, } 0.5 \text { if the lockdown is } \\
\text { localized and } 0 \text { if there is no lockdown. }\end{array}$ \\
\hline $\begin{array}{l}\text { Cancellations of sporting } \\
\text { and large events }\end{array}$ & ACAPS & IMF & $\begin{array}{l}1 \text { if the cancellation is national, } 0.5 \text { if the cancellation is } \\
\text { localized and } 0 \text { if there is no cancellation. }\end{array}$ \\
\hline Restaurant closures & ACAPS & IMF & $\begin{array}{l}1 \text { if the closure is global and national, } 0.5 \text { if the closure is } \\
\text { localized or limited (e.g., number of customers is limited) } \\
\text { and } 0 \text { if there is no closure. }\end{array}$ \\
\hline Postponement of elections & IDEA & IMF & $\begin{array}{l}1 \text { if elections are postponed, } 0.5 \text { if some elections are } \\
\text { postponed and } 0 \text { if elections were programmed but not } \\
\text { postponed. }\end{array}$ \\
\hline State of emergency & ACAPS & IMF & $\begin{array}{l}1 \text { if a state of emergency (or health emergency) is } \\
\text { implemented, } 0 \text { if not. }\end{array}$ \\
\hline Public testing & ACAPS & IMF & $\begin{array}{l}1 \text { if public testing is (or aims to be) general, } 0.5 \text { if testing is } \\
\text { done only at the hospital or if people are potentially } \\
\text { contaminated, } 0 \text { if no testing is done. }\end{array}$ \\
\hline Enhanced surveillance & ACAPS & IMF & 1 if monitoring app surveillance is active, 0 if not. \\
\hline
\end{tabular}




\section{A2. RESULTS OF THE PRINCIPAL COMPONENT ANALYSIS}

The table below reports the eigenvectors of the first component of the principal component analysis. The first component has an eigenvalue of 6.41 and explains $71.2 \%$ of the variance. Enhanced surveillance is dropped because of zero variance (few countries have implemented such surveillance).

Table A2. Eigenvectors from the principal component analysis for the first component

\begin{tabular}{|l|l|}
\hline Variables & First Component \\
\hline Bans on mass gatherings & 0.346 \\
\hline Schools closure & 0.363 \\
\hline Travel restrictions & 0.327 \\
\hline Domestic lockdown & 0.360 \\
\hline Cancellation of sporting and large events & 0.349 \\
\hline Restaurants closing & 0.329 \\
\hline Elections postponing & 0.313 \\
\hline State of emergency & 0.295 \\
\hline Public testing & 0.311 \\
\hline
\end{tabular}

\section{A3. VARIABLES USED IN THE REGRESSION ANALYSIS}

Table A3. Variables, sources and mean

\begin{tabular}{|l|l|l|}
\hline Variables & Source & Mean \\
\hline $\begin{array}{l}\text { Index of governments' } \\
\text { response to COVID-19 }\end{array}$ & Authors' calculations & 0.25 \\
\hline $\begin{array}{l}\text { Cumulated cases (\% of } \\
\text { population) }\end{array}$ & $\begin{array}{l}\text { European disease } \\
\text { and prevention } \\
\text { Center }\end{array}$ & 0.006 \\
\hline Government effectiveness & $\begin{array}{l}\text { World Bank } \\
\text { (standardized) }\end{array}$ & 0.49 \\
\hline $\begin{array}{l}\text { Health spending (\% of } \\
\text { GDP) }\end{array}$ & $\begin{array}{l}\text { World Bank } \\
\text { (standardized) }\end{array}$ & 0.193 \\
\hline $\begin{array}{l}\text { Population aged 65 and } \\
\text { more (\% of population) }\end{array}$ & $\begin{array}{l}\text { World Bank } \\
\text { (standardized) }\end{array}$ & 0.458 \\
\hline $\begin{array}{l}\text { Population density per } \\
\text { squared kilometer }\end{array}$ & $\begin{array}{l}\text { World Bank } \\
\text { (standardized) }\end{array}$ & -0.046 \\
\hline $\begin{array}{l}\text { Healthcare Access and } \\
\text { Quality (score) }\end{array}$ & $\begin{array}{l}\text { Healthcare Access } \\
\text { and Quality } \\
\text { (standardized) }\end{array}$ & 0.593 \\
\hline $\begin{array}{l}\text { Distance to China (capital } \\
\text { to capital) in kilometer }\end{array}$ & CEPII & 8067.0 \\
\hline Days after the first death & Authors' calculation & -20.71 \\
\hline
\end{tabular}

